\title{
Scratching the surface: the use of sheepskin parchment to deter textual erasure in early modern legal deeds
}

\author{
Sean Paul Doherty ${ }^{1,2^{*}}$, Stuart Henderson ${ }^{2,3}$, Sarah Fiddyment ${ }^{3}$, Jonathan Finch ${ }^{2}$ and Matthew J. Collins ${ }^{3,4}$
}

\begin{abstract}
Historic legal deeds are one of the most abundant resources in British archives, but also one of the most neglected. Despite the millions that survive, we know remarkably little about their manufacture, including the species of animal on which they were written. Here we present the species identification of 645 sixteenth-twentieth century skins via peptide mass fingerprinting (ZooMS), demonstrating the preferential use of sheepskin parchment. We argue that alongside their abundance and low cost, the use of sheepskins over those of other species was motivated by the increased visibility of fraudulent text erasure and modification afforded by the unique structure of their skin.
\end{abstract}

Keywords: Parchment, Manuscripts, Proteomics, Biocodicology, Sheepskin, Legal deeds

\section{Introduction}

By the late-sixteenth century, English common law was predominantly text-based, displacing oral tradition as the repository of legal precedent [1]. Deeds, wills and other legal instruments grew in significance amongst all social stations [2-4] as the burgeoning statute book ${ }^{1}$ increasingly necessitated formally executed documents through which an interest, right, property or obligation could be created, confirmed or transferred.

Despite the permissibility ${ }^{2}$ and growing use of paper, deeds-legal documents concerning the ownership or tenure of tangible (land or buildings) and intangible (rights or privileges) property-remained principally handwritten on animal skin (Fig. 1) [5]. The continued use of skins, despite their significantly higher cost [6-8], is likely due to their greater durability than other writing media. The enhanced longevity afforded to text written on skin rather than paper was noted by contemporary theologians and jurists alike [9-12], echoing comments of the durability of skin over papyrus a millennia earlier [13].

\footnotetext{
*Correspondence: sean@palaeome.org

1 Department of Archaeology, University of Exeter, Exeter, UK

Full list of author information is available at the end of the article
}

Such is their durability that historic legal deeds are one of the most abundant resources in British archives; but they are also one of the most neglected [14, 15]. When viewed simply as a textual resource, they are often considered to be of limited historic or scholarly value due to the considerable proportion of text taken up by formulaic rubric. Many were discarded, burnt, or even repurposed into lamp shades during the twentieth century after the Land Registry Act of 1925 (15 \& 16 Geo. 5. c.21) ceased the necessity of their retention [15-17]. We know remarkably little about the production of these commonplace legal documents. Uncertainty even remains over the animal species used, with deeds frequently catalogued as 'vellum' (etymologically meaning calfskin), 'parchment' (typically reserved for sheep or goatskin), or even more generally as 'animal membrane'.

Species identification based upon observation of hair fibres and follicle patterns that survived the manufacturing process has suggested a potential preference of

\footnotetext{
${ }^{1}$ The requirement for formally executed instruments was particularly shaped by the Statutes of Uses, 1535 ( 27 Hen. 8, c.10), Statutes of Wills, 1540 (32 Hen 8, c.1), and the Statutes of Frauds, 1677 (29 Car. 2, c.3) (1677).

2 The requirement that deeds be "written on paper or parchment" was formalised in the ruling of Goddard's Case (1584) 2 Co Rep 4b, 5a; 76 ER 396, $398-9$.
}

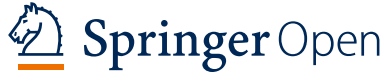

(c) The Author(s) 2021. This article is licensed under a Creative Commons Attribution 4.0 International License, which permits use, sharing. adaptation, distribution and reproduction in any medium or format, as long as you give appropriate credit to the original author(s) and the source, provide a link to the Creative Commons licence, and indicate if changes were made. The images or other third party material in this article are included in the article's Creative Commons licence, unless indicated otherwise in a credit line to the material. If material is not included in the article's Creative Commons licence and your intended use is not permitted by statutory regulation or exceeds the permitted use, you will need to obtain permission directly from the copyright holder. To view a copy of this licence, visit http://creativeco mmons.org/licenses/by/4.0/. The Creative Commons Public Domain Dedication waiver (http://creativecommons.org/publicdomain/ zero/1.0/) applies to the data made available in this article, unless otherwise stated in a credit line to the data. 


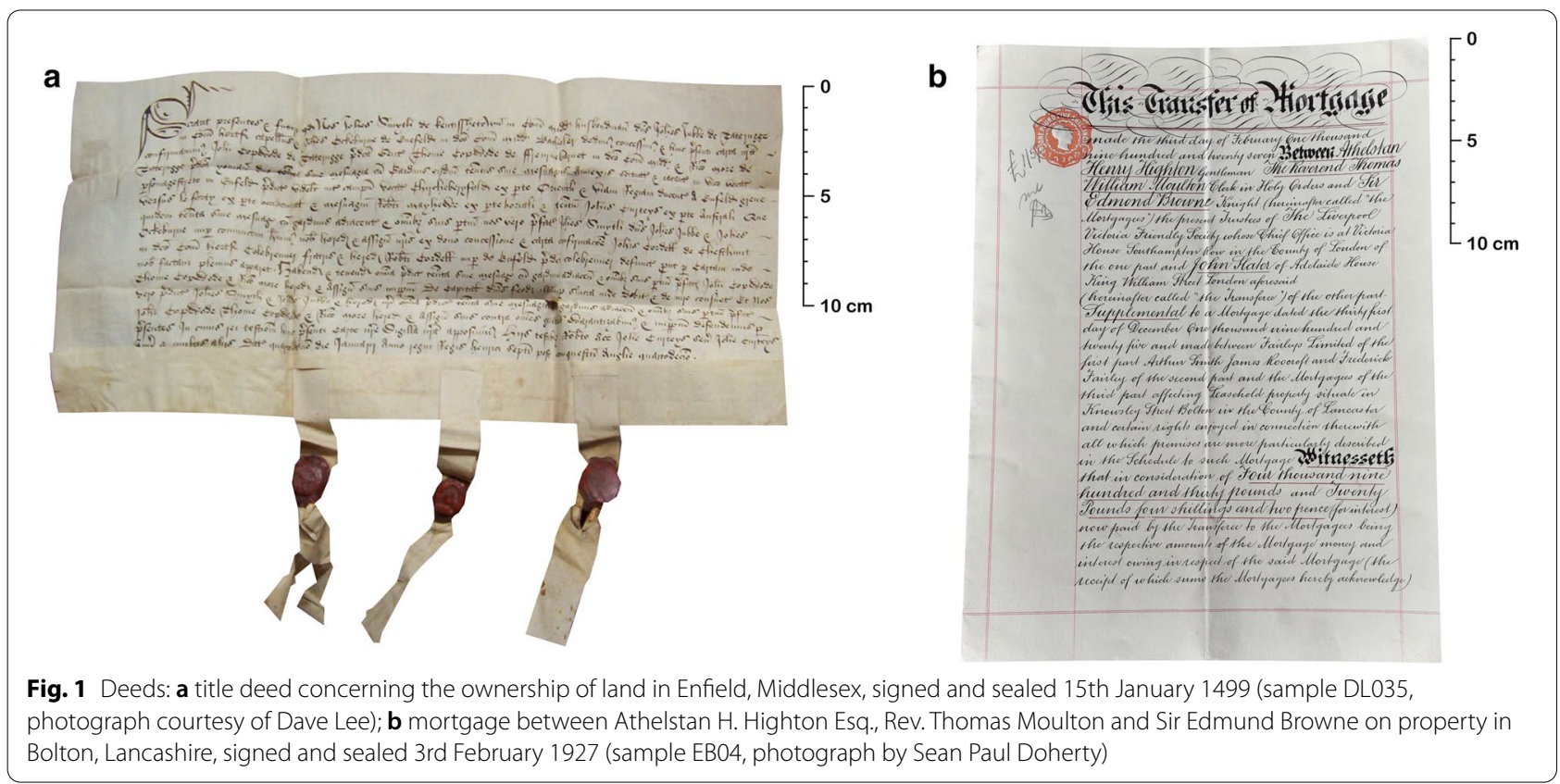

Table 1 Collection information of deeds analysed

\begin{tabular}{lrll}
\hline Collection & \multicolumn{1}{c}{ D } & Date range (AD) & Collection information \\
\hline Cheshire records office & 15 & $1786-1813$ & Artificial collection of title deeds concerning property in Cheshire \\
Doherty collection & 8 & $1913-1940$ & Artificial collection of title deeds concerning property across England and Wales \\
Hull history centre & 38 & $1596-1969$ & Artificial collection of title deeds concerning property in the East Riding of Yorkshire \\
Lee collection & 254 & $1499-1907$ & Artificial collection of title deeds concerning property across England, Wales and Scotland \\
Lincoln records office & 9 & $1742-1907$ & Artificial collection of title deeds concerning property in Lincolnshire \\
Lord collection & 50 & $1582-1893$ & Title deeds concerning Lower Winskill Farm, Settle, North Yorkshire \\
Tye collection & 254 & $1650-1904$ & Artificial collection of title deeds concerning property in the City of London. Documents \\
& & & were discarded from the Sun Fire Office, London, company archives \\
Westminster city archives & 1 & 1707 & Title deed from the City of Westminster \\
Wills collection & 16 & $1652-1790$ & Title deeds concerning property in Somerset \\
\hline
\end{tabular}

The artificial collections contain documents of different provenance, while the others have grown organically around a single property

sheepskin for legal deeds across the thirteenth-nineteenth centuries $[18,19]$. This method of identification relies on subjective identification by the user which can lead to misidentification [20], though Ryder's conclusions have been supported more recently by genetic and proteomic analyses [20-22]. Yet, despite the quantities that survive, the corpus of identified material remains limited. Here we present the species identification of 645 legal deeds from the sixteenth to twentieth century using peptide mass fingerprinting (ZooMS) and explore the potential drivers behind the choice of animal.

\section{Materials and methods}

Samples were obtained from 645 individual pages from a total of 477 deeds concerning property in England, Scotland and Wales (Table 1). Of the documents with multiple pages, each skin was of a size $(>70 \times 50 \mathrm{~cm})$ to indicate they came from a single animal. Each deed was engrossed with the day, month and year the agreement was signed. None had received any conservation treatment or presented any visual evidence for being a palimpsest (from the Ancient Greek ' $\pi \alpha \lambda i \mu \psi \eta \sigma \tau o c^{\prime}$ ' meaning 'scraped again'), where the previous text has been erased and the parchment reused, as determined via gross examination. Physical samples $\left(0.2 \mathrm{~cm}^{2}\right)$ were removed from the edge of each leaf from areas devoid of any ink, pencil, stamp, glue or surface marking to avoid contamination. 


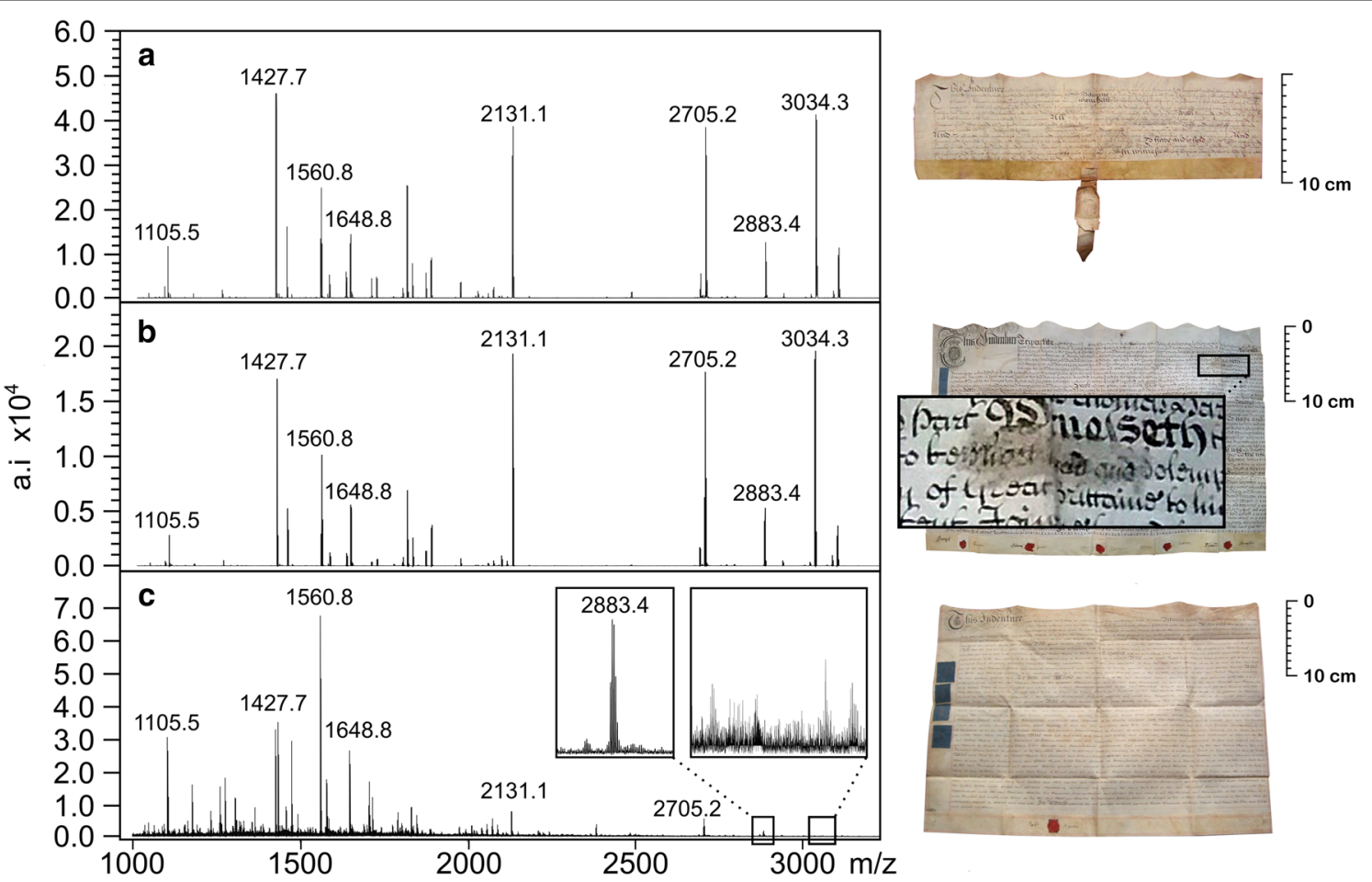

Fig. 2 Peptide mass fingerprint from samples. a DL157, an indenture concerning property in Bennington, Hertfordshire, signed 20 th May 1687. Identified as sheepskin based on diagnostic peptide markers, particularly at 3034.3 (m/z) [25]. b DL189, a tripartite marriage settlement signed 14th November 1737 in Atterton, Leicestershire. Identified as sheepskin based on diagnostic peptide markers. Note the visible erasure of text amending the intended date of the wedding. c DL149, an indenture concerning property in Knaresborough, North Yorkshire, signed 3rd June 1800. While the peptide marker at 2883.4 indicates it is either sheep or goatskin and not calfskin (Bos taurus) the absence of diagnostic peptide markers at 3034.3 (sheep) and 3094.3 (goat) [25] precludes separation of these species (photographs of deeds courtesy of Dave Lee)

Samples were placed in individual $1.5 \mathrm{ml}$ microcentrifuge tubes, $75 \mu \mathrm{l}$ of $0.05 \mathrm{M}$ ammonium bicarbonate $\left(\mathrm{NH}_{5} \mathrm{CO}_{3}\right)$ buffer added, along with $1 \mu$ of porcine trypsin $(0.47 \mu \mathrm{g} / \mu \mathrm{l})$ (Promega, WI, USA) and incubated at $65^{\circ} \mathrm{C}$ to gelatinise. After $4 \mathrm{~h}, 1 \mu \mathrm{l}$ of trifluoroacetic acid (TFA) $(5 \% \mathrm{vol} / \mathrm{vol})$ was added to cease enzymatic digestion. The digest was desalted and purified using $\mathrm{C}_{18}$ solid-phase tips (Agilent ZipTip, CA, USA), and the peptides eluted in a final solution of $50 \mu \mathrm{l}, 50 \%$ acetonitrile/0.1\% TFA ( $\mathrm{vol} / \mathrm{vol}) .1 \mu \mathrm{l}$ of eluted peptides was mixed on a ground steel plate with $1 \mu \mathrm{l}$ of $\alpha$-cyano-4-hydroxycinnamic acid matrix solution [ $1 \%$ in $50 \%$ ACN/0.1\% TFA (vol/vol)] and allowed to co-crystallise. All samples were spotted in triplicate. Samples were analysed using a Bruker Ultraflex II (Bruker Daltonics, Bremen, Germany) MALDITOF instrument equipped with a Nd:YAG smart beam laser. Samples spectra were calibrated against an adjacent calibrant spot with six calibration peptides. The resulting mass spectra were analysed within mMass software (https://www.mmass.org) [23], and individual peptides manually identified according to published markers [24, 25].

\section{Results}

All 645 samples were identified as animals of the Bovidae family, of which 622 (96.4\%) were identified as sheep (Ovis aries). The remaining 23 (3.6\%) could be classified as sheep or goat (Capra aegagrus hircus), but separation between the species was not possible due to the lack of diagnostic peptides (Fig. 2). Protein survival in parchment can be reduced via oxidation, hydrolysis and biological attack during storage [26, 27], and likely affected the presence of diagnostic peptides within these samples. These samples came from a range of collections and the absence of sufficient diagnostic peptides does not appear to be related to their age or storage location. This highlights the potential limitation of this biomolecular technique and the continued role that fibre and follicle analysis has in the identification of historic parchment. It is highly likely that most, if not all samples are sheepskin, but acknowledging the visual identification of goatskin by Ryder [18] in contemporary documents, the presence of this species can not be ruled out. 


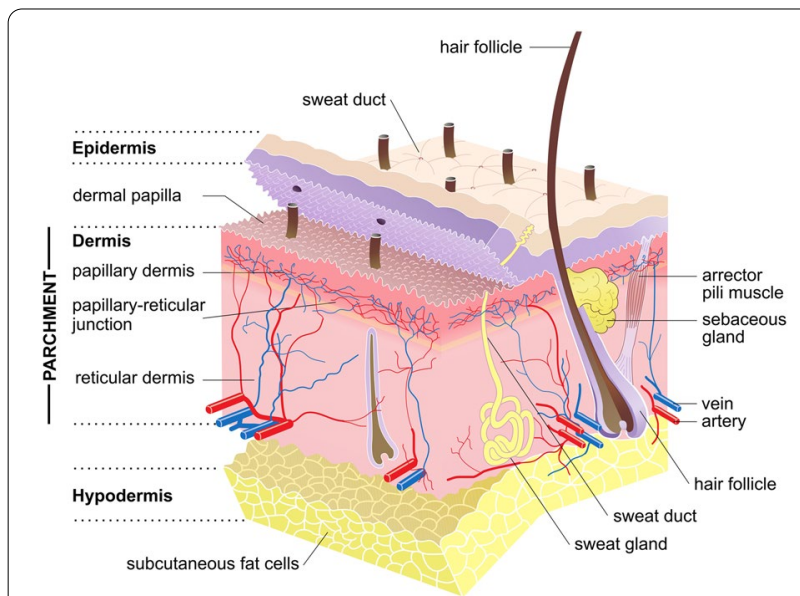

Fig. 3 Structure of sheepskin and the layers typically present in parchment (Sean Paul Doherty, Wikimedia Commons)

\section{Discussion}

Although de Hamel [28] contends that neither the scribe or recipient knew nor cared what animal the parchment was made from, the evidence suggests otherwise; sheepskin parchment was preferentially selected over that of calf or goat for legal deeds, a selection which extends back to at least the thirteenth-fourteenth century in England, Wales and Ireland [18-20, 22, 29].

The roots of this preference may lie in early efforts to impede the fraudulent modification of legal agreements after signing due to the increased visibility of erasure and text alterations afforded by sheepskin. Parchment is made from the dermis layer of skin, a layer divided into the fine dermal fibres of the upper papillary dermis and larger fibres of the lower reticular dermis (Fig. 3). This intersection is characteristically weak in sheepskin due to the abrupt change in structure and the presence of cutaneous lipids which form within the papillary-reticular junction [30, 31]. If large quantities of lipids are removed during processing, particularly through the saponification of triglycerides during liming, this can produce voids facilitating the detachment-'delamination'-of the two layers.

Sheepskin has an inherently high lipid content, accounting for as much as $30-50 \%$ of the dermis dry weight, compared to $2-3 \%$ in cattle and $3-10 \%$ in goatskin [32-36]. Over half is saponified during liming [33, 37], with more removed during subsequent washing, shaving and degreasing steps. Consequently, the potential for scraping to delaminate these layers is considerably greater in sheepskin than those of other animals.

This increased visibility of textual manipulation is noted in the twelfth century Dialogus de Scaccarioattributed to Richard FitzNeal (1130-1189), Lord Treasurer during the reigns of Henry II and Richard I-which instructs scribes of the treasury to use of sheepskins "for they do not easily yield to erasure without the blemish being apparent" [38]. This sentiment prevailed into the seventeenth century, when Sir Edward Coke-Lord Chief Justice of the King's Bench and foremost jurist of the early modern era-noted in his seminal Institutes of the Laws of England the necessity that deeds were written on a durable material such as parchment "for the writing upon these is least liable to alterations or corruption" [9]. Wakelin's [39] survey of scribal correction found that in Tudor Royal accounts (documents likely written on sheepskin parchment) errors during writing were not scraped away and overwritten but crossed out and interlineation inserted between sentences, perhaps in acknowledgement of this risk.

The greater visibility of textual erasure afforded by sheepskin was undoubtedly a factor in the development of this preference, but their long-lasting predominance was likely due in no small part to their great abundance and relatively low cost. Estimating the size of the British sheep population prior to the introduction of official agricultural statistics has proved difficult $[40,41]$, however, it is likely that there were between 10 and 17 million sheep across the twelfth to seventeenth centuries, 11-14 million by the early eighteenth century and continuing to grow to over 25 million by the late-nineteenth century. With an average culling rate of around $20 \%$ during this period [42, 43], roughly 2-5 million skins would have been yielded annually, more than enough to meet the demands of British skin processors [42]. In contrast, the goat population of Britain has historically been very low $[44,45]$.

While sheepskins of any age can be used for parchment, only those from calves younger than around 6 weeks old can be used for vellum due to their rapidly increasing thickness [46]. The total number of calves is unlikely to have exceeded 1 million until the nineteenth century, of which only a few hundred thousand skins may have been yielded annually [47], particularly during the prohibiting of killing calves under 5 weeks between 1604 and $1671 .^{3}$ The limited supply of calfskin, and its perceived higher quality, meant that vellum was more than double the price of sheepskin parchment [6-8]. Even the finest quality sheepskin was cheaper than the poorest quality vellum, as attested in the fourteenth century account books of Beaulieu Abbey [48]. In 1593, a dozen

\footnotetext{
3 The prohibition was established by An Act Concerning Tanners, Curriers, Shoe Makers, and other artificers occupying the cutting of Leather, 1604 (1 Jac. I. c.22), but repealed by An Act to prevent Fraudes in the buying and selling of Cattell in Smithfeild and elsewhere, 1671, (22 \& 23 Car. 2, c.19).
} 
sheets of parchment cost on average $8 s$, while the same amount of vellum was more than double at 20 s; by 1660 , a dozen sheets of parchment cost $10 s$ and vellum $28 s$ [7], and more than double the levy of tax. ${ }^{4}$ Prior to the shortlived Flaying Acts ${ }^{5}$ (1800-1824), sheepskins were also exempt from the often costly inspection by 'searchers and sealers' which was required prior to processing for from calves, bulls, steers, deer and goats, ${ }^{6}$ likely making the former cheaper and more easily accessible. Consequently, for common legal documents, sheepskin parchment presented the ideal inexpensive and durable material.

\section{Conclusion}

From the thirteenth to twentieth century, parchment legal deeds were almost exclusively written on sheepskin, rather than goatskin or calfskin vellum. This preferential use likely began due to the high fat content of sheepskins and their subsequent propensity to delaminate and deform when scraped, highlighting any attempts to modify the text after signing. Their abundance, low-cost and lower stamp duty throughout much of the early modern period supported the continuation of this practice through to at least late-nineteenth century.

While the text enshrined in these early modern deeds may be considered by some to be of limited historic value, as physical objects they are an extraordinarily high resolution zooarchaeological and molecular archive through which centuries of craft, trade and livestock economies can be explored. Once again, we have demonstrated how the growing field of 'biocodicology' [49] can bring life to the official archives and record offices, which Frederick Maitland [50] called the "mausoleum of parchment".

\section{Supplementary Information}

The online version contains supplementary material available at https://doi. org/10.1186/s40494-021-00503-6.

Additional file 1: Dataset S1. Scratching the Surface: the use of sheepskin parchment to deter textual erasure in early modern legal deeds

\section{Acknowledgements}

The authors thank Tom Lord, Dave Lee, Ray Tye, Mr and Mrs Wills, Cheshire Records Office, Hull History Centre, Lincoln Records Office and Westminster City Archives for the generous donation of parchment for analysis. The Centre for Excellence in Mass Spectrometry, University of York, is thanked for access to MALDI-TOF-MS.

\section{Authors' contributions}

SPD and MJC conceived the study. SPD, SF and MJC collected the samples. SPD prepared samples for MALDI-TOF-MS and interpreted data. SPD wrote the manuscript with input from SH, SF, JF and MJC. All authors read and approved the final manuscript.

\section{Funding}

S.P.D. was supported by funding from the AHRC White Rose College of Arts \& Humanities Doctoral Training Partnership (Award No. 1489527). S.F. and M.J.C. were supported by ERC Investigator Grant 295729-CodeX.

Availability of data and materials

Additional file 1: Dataset S1—Sample information and species identification.

\section{Competing interests}

The authors declare no competing interests.

\section{Author details}

${ }^{1}$ Department of Archaeology, University of Exeter, Exeter, UK. ${ }^{2}$ Department of Archaeology, University of York, York, UK. ${ }^{3}$ McDonald Institute for Archaeological Research, University of Cambridge, Cambridge, UK. ${ }^{4}$ Section for Evolutionary Genetics, GLOBE Institute, University of Copenhagen, Copenhagen, Denmark.

Received: 8 January 2021 Accepted: 17 February 2021

Published online: 25 March 2021

\footnotetext{
${ }^{4}$ Taxation of skins for legal deeds was established by the Stamps Act, $1694(9$ Ann. c.11). The duties levied changed significantly over the proceeding centuries but all were repealed by the Stamps Act, 1815 (55 Geo. III c.184).

${ }^{5}$ Skin inspections were created in 1804 (39 \& 40 Geo 3, c. 6) and abolished in 1824 ( 5 Geo. 4, c. 57).

${ }^{6}$ Although sheepskins were mentioned in the initial 1604 Act (1 Jac 1, c.22), the 1606 Act (4 Jac. 1, c.6) clarified that they were not subject to sealing.
}

References

1. Ross R. The memorial culture of early modern english lawyers: memory as keyword, shelter and identity, 1560-1640. Yale J L Human. 1998;10:229-326.

2. Brooks CW, Helmholz RH, Stein P. Notaries public in England since the reformation. Norwich: The Erskine Press; 1991.

3. Erickson AL. Women and property: in early modern England. London: Routledge; 1995.

4. McCunn JH. The interpretation of deeds and wills at common law, Ph.D. Thesis, University of Cambridge; 2019. p.c.1536-616.

5. The Law Commission. The execution of deeds and documents by or on behalf of bodies corporate. The Law Commission, Report No. 226-224-1; 2015.

6. Rogers JET. A history of agricultural prices in England: from the year after the Oxford Parliament (1259) to the commencement of the Continental War (1793). Vol I. Oxford: The Clarendon Press; 1866. p. 1259-400.

7. Rogers JET. A history of agricultural prices in England: from the year after the Oxford Parliament (1259) to the commencement of the Continental War (1793). Vol III. Oxford: The Clarendon Press; 1881. p. 1401-582.

8. Rogers JET. A history of agricultural prices in England: from the year after the Oxford Parliament (1259) to the commencement of the Continental War (1793). Vol V. Oxford: The Clarendon Press; 1887. p. 1582-702.

9. Coke $E$. The first part of the institutes of the lawes of England. 1st ed. London: Printed for the Societe of Stationers; 1628 
10. Blackstone W. Commentaries on the laws of England, in four books. Vol.1. London: A Strahan; 1767.

11. Eisenstein EL. The printing press as an agent of change. Cambridge: Cambridge University Press; 1980.

12. Müller J-D. The body of the book: the media transition from manuscript to print. In: Finkelstein D, Mccleery A, editors. The book history reader. London: Routledge; 2002. p. 143-50.

13. Hulley KK. Light cast by St. Jerome on certain palaeographical points. Harv Stud Classic Philol. 1943;54:83-92.

14. Cornwall J. Reading old title deeds. 2nd ed. Birmingham: Federation of Family History Societies; 1997.

15. Alcock N. Tracing history through title deeds: a guide for family and local historians. Barnsley: Pen and Sword; 2017.

16. Windsor J. There's a lot more to title deeds than pretty pieces of parchment John-Windsor reads between the lines. The Independent; 1997.

17. Howell J. Deeds registration in England: a complete failure? Camb Law J. 1999;58:366-98.

18. Ryder ML. Follicle remains in some British parchments. Nature. 1960;187:130-2.

19. Ryder ML. The histological examination of skin in the study of the domestication of sheep. Zeitschrift für Tierzüchtung und Züchtungsbiologie. 1962;77:168-71.

20. Fiddyment S, Holsinger B, Ruzzier C, Devine A, Binois A, Albarella U, et al. Animal origin of 13 th-century uterine vellum revealed using noninvasive peptide fingerprinting. Proc Natl Acad Sci. 2015;112:15066-71.

21. Teasdale MD, van Doorn NL, Fiddyment S, Webb CC, O'Connor T, Hofreiter $M$, et al. Paging through history: parchment as a reservoir of ancient DNA for next generation sequencing. Philos Trans R Soc Lond B Biol Sci. 2015;370:20130379.

22. Teasdale M, Fiddyment S, Vnouček J, Mattiangeli V, Speller C, Binois A, et al. The York Gospels: a 1000-year biological palimpsest. R Soc Open Sci. 2017:4:170988.

23. Strohalm M, Kavan D, Novák P, Volný M, Havlícek V. mMass 3: a crossplatform software environment for precise analysis of mass spectrometric data. Anal Chem. 2010;82:4648-51.

24. Buckley M, Collins M, Thomas-Oates J, Wilson JC. Species identification by analysis of bone collagen using matrix-assisted laser desorption/ionisation time-of-flight mass spectrometry. Rapid Commun Mass Spectrom. 2009;23:3843-54.

25. Buckley M, Whitcher Kansa S, Howard S, Campbell S, Thomas-Oates J, Collins M. Distinguishing between archaeological sheep and goat bones using a single collagen peptide. J Archaeol Sci. 2010;37:13-20.

26. Badae E, Miu E, Budrugeac P, Giurginca M, Masic A, Badea N, et al. Damage ranking of historic parchment: from microscopic studies of fibre structure to collagen denaturation assessment by Micro DSC. Preserv Sci. 2012;9:97-109.

27 Brock F, Geoghegan V, Thomas B, Jurkschat K, Higham TFG. Analysis of bone "collagen" extraction products for radiocarbon dating. Radiocarbon. 2013;55:445-63.

28. de Hamel C. Medieval craftsmen: scribes and illuminators. London: British Museum; 1992.

29. Lévêque É. An Irish sheep tale—700 year-old parchments conserved. National Library of Ireland. 2013. https://blog.nli.ie/index .php/2013/05/24/an-irish-sheep-tale-700-year-old-parchments-conse rved/. Accessed 2 Jan 2021.

30. Reed R. Ancient skins, parchments and leather. London: Seminar Press; 1973.

31. Covington AD. Tanning chemistry: the science of leather. London: Royal Society of Chemistry; 2009.

32. Koppenhoefer RM. The lipids of sheepskins. I. Lipid of fresh sheepskin. J Am Leather Chem As. 1938;33:203-15.

33. Koppenhoefer RM. The lipids of sheepskins. II. The effect of pullery processes on the lipids of sheep skin. J Am Leather Chem As. 1939;34:100-12.

34. Bieńkiewicz JK. Physical chemistry of leather making. Malabar: Krieger; 1983.

35. Ockerman HW, Hansen CL. Animal by-product processing \& utilization. Washington, DC: CRC Press; 1999.

36. Palop R. Sheepskin and cattle hide degreasing. Barcelona: Cromogenia Linits; 2016.
37. McLaughlin GD, Theis ER. The chemistry of leather manufacture. New York: Reinhold Publishing Corporation; 1945.

38. Henderson EF. Select historical documents of the middle ages: translated and edited by Ernest F. Henderson. London: Bell \& Sons; 1912.

39. Wakelin D. Scribal correction and literary craft, English manuscripts 1375-1510. Cambridge: Cambridge University Press; 2014.

40. Fussell GE, Goodman C. Eighteenth century estimates of British sheep and wool production. Agr Hist Soc. 1930;4:131-51.

41. Turner M. Counting sheep: waking up to new estimates of livestock numbers in England c1800. Agr Hist Rev. 1998;47:142-61.

42. Clarkson LA. The manufacture of leather. In: Mingay GE, editor. The agrarian history of England and Wales, Vol VI, 1750-1850. Cambridge: Cambridge University Press; 1989. p. 466-85.

43. Clark G. Labour productivity in English agriculture, 1300-1860. In: Campbell B, Overton M, editors. Land, labour and livestock: historical studies in European agricultural productivity. Manchester: Manchester University Press; 1991. p. 211-35.

44. Albarella U. Tanners, tawyers, horn working and the mystery of the missing goat. In: Murphy P, Wiltshire P, editors. The environmental archaeology of Industry. Oxford: Oxbow Books; 2003. p. 71-86.

45. Dyer C. Alternative agriculture: goats in medieval England. In: Hoyle RW, editor. People, Landscape and alternative agriculture: essays for Joan Thirsk. Exeter: British Agricultural History Society; 2004. p. 20-38.

46. La lande JJ de. Art de Faire le parchemin. Paris: Guerin \& Delatour; 1762.

47. Broadberry S, Campbell BMS, Klein A, Overton A, van Leeuwen B. British economic growth, 1270-1870. Cambridge: Cambridge University Press; 2015.

48. Gullick M. From parchmenter to scribe: some observations on the manufacture and preparation of medieval parchment based on a review of the literary evidence. In: Rück P, editor. Pergament: geschichte, struktur, restaurierung, herstellung. Sigmaringen: J. Thorbecke; 1991. p. 143-57.

49. Fiddyment S, Teasdale MD, Vnouček J, Lévêque É, Binois A, Collins MJ. So you want to do biocodicology? A field guide to the biological analysis of parchment. Herit Sci. 2019;7:35.

50. Maitland FW. The collected papers of Frederic William Maitland. Cambridge: Cambridge University Press; 2013.

\section{Publisher's Note}

Springer Nature remains neutral with regard to jurisdictional claims in published maps and institutional affiliations.

\section{Submit your manuscript to a SpringerOpen ${ }^{\circ}$ journal and benefit from:}

- Convenient online submission

- Rigorous peer review

- Open access: articles freely available online

- High visibility within the field

- Retaining the copyright to your article

Submit your next manuscript at $\gg$ springeropen.com 